\title{
Investigating the impact of root-knot nematode double infection on bacterial wilt of tomato
}

\author{
Muhammad Junaid*, Musharaf Ahmad and Saifullah \\ Department of Plant Pathology, TheUniversity of Agriculture Peshawar-Pakistan \\ *Corresponding author's email: mjunaid27@yahoo.com \\ Citation
}

Muhammad Junaid, Musharaf Ahmad and Saifullah. Investigating the impact of root-knot nematode double infection on bacterial wilt of tomato. Pure and Applied Biology. Vol. 9, Issue 2, pp1347-1353.

http://dx.doi.org/10.19045/bspab.2020.90141

\begin{tabular}{llll}
\hline \hline Received: 15/11/2019 & Revised: 21/01/2020 & Accepted: 28/01/2020 & Online First: 24/02/2020 \\
\hline \hline
\end{tabular}

\section{Abstract}

To check the possibility of double infection of tomato plants by root-knot nematodes (RKN), Meloidogyne spp., and tomato wilt bacterium, Ralstonia solanacearum, pot experiments was conducted in the green house, department of Plant Pathology, the University of Agriculture Peshawar. Four treatments consisting bacteria and/or nematode (alone or in combination) were investigated on five tomato varieties i.e. Lyreka, Money-maker, Red-stone, Rachna and ReoGrand. Results stated that when RKN was inoculated together with $R$. solanacearum, severity of bacterial wilt enhanced while the yield was reduced significantly. Maximum number of plants (96\%) survived when plants were not inoculated with bacterium. However, with double-inoculation 77.33\% plant survived. Similarly, maximum (3.33) disease ratings were recorded when plants were double-inoculated. Yield was reduced from $2.44 \mathrm{~kg}$.plant ${ }^{-1}$ to its minimum $\left(0.54 \mathrm{~kg} \cdot\right.$ plant $\left.^{-1}\right)$ when plants were double-inoculated. It was concluded that that RKN having a synergistic effect on bacterial wilt diseases, if inoculated together with $R$. solanacearum and it is recommended RKN should be managed properly to reduce the impact of bacterial wilt disease in tomato.

Keywords: Bacterial wilt; $R$. solanacearum; Root-knot nematode; Tomato

\section{Introduction}

Tomato (Lycopersicon esculentum Mill.), belonging to family solanaceae (night shade family), is one of the important vegetable throughout the world [1]. The lead producers of tomatoes are China, India, United States, and Turkey, producing $50.55,18.23,12.57$ and 11.82 million tonnes, respectively. With annual production of 0.57 million tonnes, Pakistan ranked $34^{\text {th }}$ in the world in terms of tomato production. Average per hectare yield of tomato in Pakistan was $9864 \mathrm{~kg} / \mathrm{ha}$, compared to the world's average $(35000 \mathrm{~kg} / \mathrm{ha})$ it is very low. In average per hector production of tomato Pakistan ranks $142^{\text {th }}[2,3]$. Currently, more than 200 pests and diseases have been identified in tomato, causing losses in their production directly or indirectly [4]. Including other abiotic factors the major cause of this low production are different tomato diseases, caused by viruses, nematodes, fungi and bacteria [5]. Tomato blight, wilts, root-knot and cankers are very common and important diseases. Tomato bacterial wilt caused by Ralstonia solanacearum (Smith). is considered to be one of the most important diseases due to its destructive nature.It is most important soil-borne plant pathogens that cause bacterial wilt in over 200 families of plants, including tomatoes [6]. R. solanacearum-caused wilt in tomato amounts to a $35 \%-90 \%$ yield loss under high temperatures and high moisture conditions [7]. 
As the bacterium is soil born in nature and can spread with irrigation (drainage) water, in soil,it survives for varying periods of time. Entry into plants is by way of injured roots, stem wounds or through stomata. Within the plant, bacteria move quicker in the stalk than in the roots [8]. Control of bacterial wilt has proved to be very difficult. Soil fumigants showed either slight or no effects [9]. Strict quarantine measures on infected fields and farms, sufficient crop rotation, avoidance of surface water for irrigation, control of weed hosts, volunteer plants and the most important control of nematodes are key factors in control of $R$. solanacearum.

Root-knot and cyst nematodes have been found to predispose plants to heavier infection by other pathogens [10-13]. Rootknot nematodes (RKN), Meloidogyne spp., are of great importance in severe outbreaks of bacterial wilt [14], as nematode cause injuries on roots for its own entry and nutrient uptake but the same injuries are used by the bacteria present in the soil. Sometimes double infection of RKN and $R$. solanacearum resulted in significant increase in severity of bacterial wilt evenon (bacterial wilt) resistant tomato cultivars $[14,15]$. RKN predispose tomato plants to bacterial wilt by severely injuring and making them week. Wounding reduces the time needed for bacterial invasion in the root system [16]. The role of RKN in increasing bacterial wilt severity is needed to be investigated in order finding new, environment-friendly components of the IDM against bacterial wilt disease which is economically most important diseases of tomato crop. Therefore, present research was designed with the objective to investigate the effect of bacterium-RKN double infection on bacterial wilt of tomato.

\section{Materials and methods}

To check the possibility of double infection of tomato plants by root-knot nematodes as well as $R$. solanacearum, pot experiments was conducted in the green house at The University of Agriculture, Peshawar, using completely randomized design, replicated three times. Four treatments were prepared as $\mathrm{T} 1=\mathrm{BaNa}$ (Control treatment i.e. No bacteria, No nematode), T2= $\mathrm{BpNa}$ (Bacteria inoculated, Nematode not inoculated), $\quad \mathrm{T} 3=\mathrm{BpNp} \quad$ (Bacteria inoculated, Nematode inoculated) and T4= BaNp (Bacteria not inoculated, Nematode inoculated). Additionally, five locally grown tomato varieties i.e. Lyreka, Moneymaker, Red-stone, Rachna and Reo-Grand (regardless there susceptibility or resistance to $\mathrm{BW}$ ) were used in the experiment, for more precise confirmation of the occurrence of bacterium- RKN double infection.

\section{Preparation of Nematode inoculum}

Nematode inoculum was papered with help of the procedures of Atamian et al. [17]. Root knot nematode infected roots of tomato, potato and okra (alternate hosts for RKN) plants ware collected from naturally infected field in a survey of Malakend areas of Khyber Pakhtunkhwa, used for nematode inoculum. One day before inoculation, the roots were kept in sterilized distilled water for overnight at room temperature and then chopped with a needle. Nematode egg masses were carefully isolated from the roots under stereo-microscope, and transferred to an eppendorf tube (ten in each) in sterilized $0.85 \%$ saline solution and stored it at $4^{\circ} \mathrm{C}$ for incoulation to plants later.

\section{Preparation of bacterial inoculum}

Due to high virulence based on colony morphology (i.e., white mucoid colonies with pink centers) [18] PCR confirmed (with RS-specific primers) bacterial isolate RS14-PES1 (Bacterial culture bank, Deptt. Plant Pathology, The University of Agriculture Peshawar) was grown on Nutrient Agar for 24 hours, scrapped off the plates and stored in solution of $100 \mathrm{~g}$ skimmed milk and $10 \mathrm{~g}$ Na-glutamate per litter at $-20^{\circ} \mathrm{C}$ for ( 24 hours) to avoid possible development of non-pathogenic mutants. The stock culture was thawed, streaked on the TTC (2,3,5-triphenyltetrazolium chloride) medium and incubated at $30^{\circ} \mathrm{C}$ for 48 hours. Bacteria 
were collected with sterilized scalpel and suspended into $0.85 \%$ saline sterilized distilled water. The concentration was adjusted to $10^{7}$ cell.ml $^{-1}$ (using photospectrometer with $\mathrm{OD}_{600}$ ) for inoculation to plants.

\section{Preparation of plant material}

Seedlings of each variety were separately raised in peat soil in green house at $25 \pm 5^{\circ} \mathrm{C}$. After 30 days of sowing, seedlings were transplanted to the earthenpots (with diameter $40 \mathrm{~cm}$ ). Environmental and soil condition were kept same for all varieties (as all the varieties used in the experiment were local). Similarly, plant nutrition, water requirements and cultural practices were also kept constant.

\section{Inoculation of bacteria and Nematode to plants}

Before transplanting seedling to the earthen pots. Ten nematode eggmasses (approximately 5000 eggs) were applied to each earthen pot and watered it well in order to provide hatching conditions to the nematode eggs. After three days of nematode inoculation to soil the seedling were transplanted to earthen pots. However each seedling was dipped in the bacterial suspension $\left(10^{7}\right.$ cell. $\left.\mathrm{ml}^{-1}\right)$ for 30 seconds before transplantation.

The plants were regularly observed for the symptoms development. Data was recorded for different parameters including plants survival, number of flowers, number of fruits, plant height, disease severity and yield etc. However, the three most important parameters i.e. percent survival of plants, Disease severity and yield of the plants were used for analysis. For percent survival of the plants number of plants were counted after one week of inoculation. For disease severity recording the rating scale (0-4) Swanson et al. [19] was used with some minor modifications (Table1); (i.e. as the original scale was consisting with only three ratings; no wilting, less than $50 \%$ plant showing wilting and more than $50 \%$ plant showing wilting).

Table 1. Disease rating scale for Bacterial wilt of tomato

\begin{tabular}{|c|c|c|}
\hline S. No. & Rating & Description \\
\hline 1 & 0 & no symptoms of wilting \\
\hline 2 & 1 & 0 to $25 \%$ of plant showing wilting \\
\hline 3 & 2 & 26 to $50 \%$ of plant showing wilting \\
\hline 4 & 3 & 51 to $75 \%$ of plant showing wilting \\
\hline 5 & 4 & 76 to $100 \%$ showing wilting \\
\hline
\end{tabular}

\section{Results \\ Bacterium-RKN double infection Percent plant survival}

Graphical data regarding survival percentage of the plants inoculated with RS and RKN are presented in (Figure $1 \& 4$ ). All the treatments, varieties and interactions were found highly significant. For treatments, maximum number of plants (96\%) survived treatment 1 and 4 where plants were not inoculated with bacterium. Statistically similar (non-significant) (80.67\% and $77.33 \%$ ) results were obtained in terms of plant survival for both the treatments 2 and 3 respectively, where plants were inoculated with the bacterium. On the other hand maximum (91.67\%) number of plants survived for variety M.maker followed by both Lyreka and R. grand $(88.33 \%$ each), while minimum $(82.5 \%)$ number of plants survived for variety Rachna.

\section{Disease severity}

For disease severity, Graphical data regarding are presented in (Figure $2 \& 4$ ). All treatments were found highly significant. For treatments maximum (3.33) disease ratings were recorded for treatment 3 where plants were inoculated with bacterium and nematode combined. It was followed by treatment 2 with 1.80 disease ratings, where plants were inoculated with the bacterium only, while treatment 1 (control) and treatment 4 (inoculated only 
with nematode) also showed some disease ratings i.e. 0.27 and 0.33 respectively but it was negligible and might be due to infected soil or inoculums spread during cultural practices. On the other hand behavior of varieties to the disease severity was nonsignificant.

\section{Yield (kg.plant ${ }^{-1}$ )}

Data regarding yield in kg.plant ${ }^{-1}$ are presented in (Figure 3\&4). All the treatments, varieties and interactions were found highly significant. For treatments, maximum (2.44 kg.plant $\left.{ }^{-1}\right)$ yield was obtained for treatment 1 (control) where plants were keptnon-inoculated with bacterium and/or nematode. It was followed by treatment 2 with $1.74 \mathrm{~kg}$. plant 1 , where plants were inoculated with the bacterium only. While treatment 3 (inoculated with bacteria and nematode both) showed minimum $(0.54 \mathrm{~kg})$ yield.plant ${ }^{-1}$. On the other hand variety $\mathrm{M}$. maker was best yielding variety with 1.78 kg.plant ${ }^{-1}$ yield, followed by R. stone with $1.56 \mathrm{~kg}$ plant $^{-1}$, whereas, variety Rachna was lowest $\left(1.38 \mathrm{~kg}\right.$. plant $\left.^{-1}\right)$ yielding variety. It was also observed that the treatment showing low disease score gave more yield and vice-versa (Figure 5).

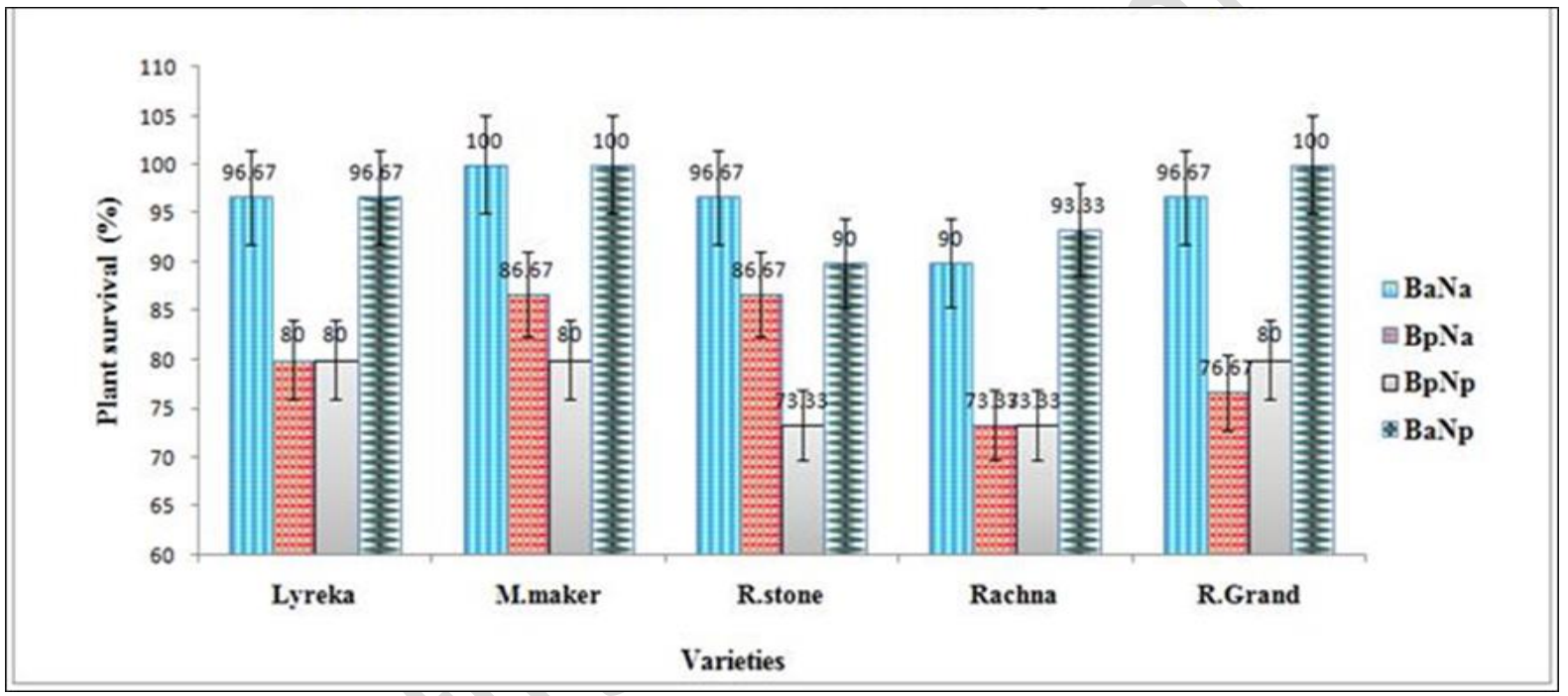

$\mathrm{B}=$ Bacteria, $\mathrm{N}=$ Nematode, $\mathrm{a}=$ absent, $\mathrm{p}=$ present, LSD $(\mathrm{P} \leq 0.05)$ for Treatments $=3.91$, LSD $(\mathrm{P} \leq 0.05)$ for Varieties $=4.37, \operatorname{LSD}(\mathrm{P} \leq 0.05)$ for Treatments $\mathrm{x}$ Varieties $=8.74$

Figure 1. Effect of Bacterium-RKN double infection on plant survival (\%)

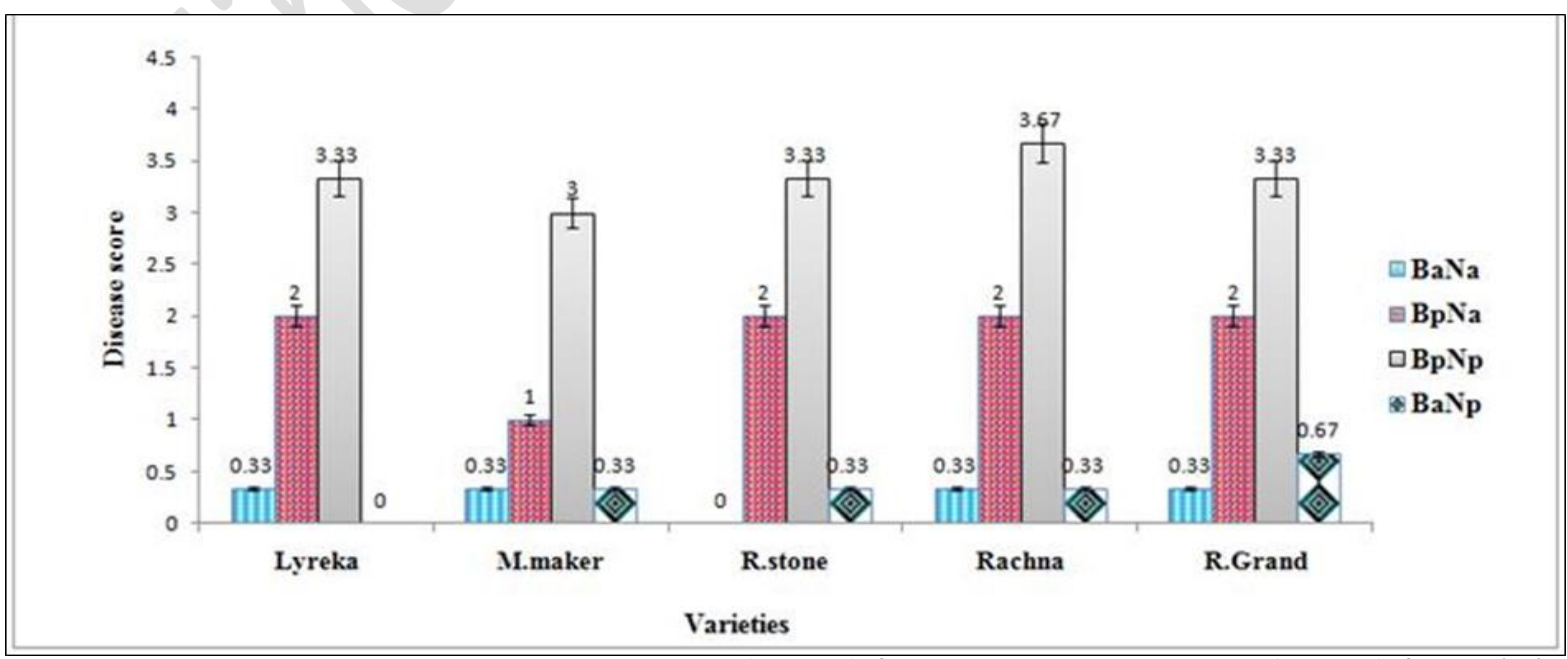

Bacteria, $\mathrm{N}=$ Nematode, $\mathrm{a}=$ absent, $\mathrm{p}=$ present, LSD $(\mathrm{P} \leq 0.05)$ for Treatments $=0.32$, LSD $(\mathrm{P} \leq 0.05)$ for Varieties $=0.36$, LSD $(\mathrm{P} \leq 0.05)$ for Treatments $\mathrm{x}$ Varieties $=0.73$

Figure 2. Effect of Bacterium-RKN double infection on disease severity 


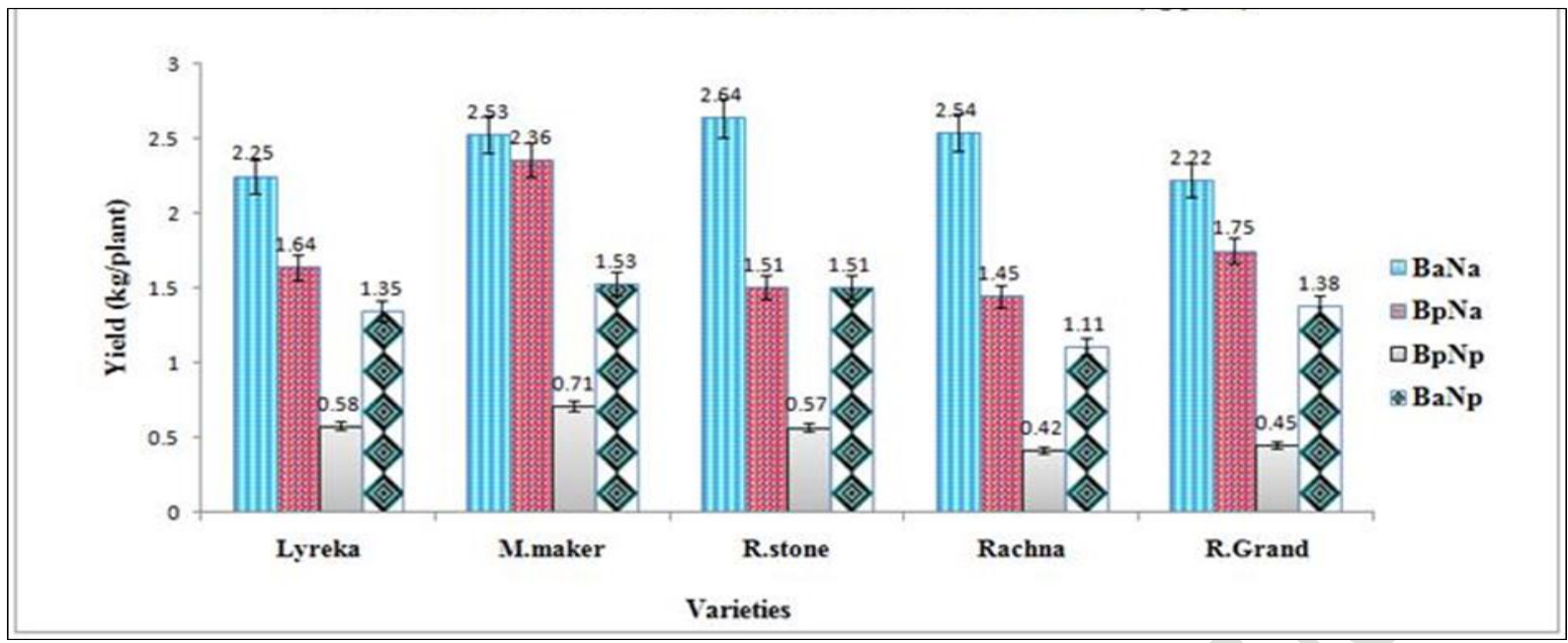

$\mathrm{B}=$ Bacteria, $\mathrm{N}=$ Nematode, $\mathrm{a}=$ absent, $\mathrm{p}=$ present, $\mathrm{LSD}(\mathrm{P} \leq 0.05)$ for Treatments $=0.15$, $\mathrm{LSD}(\mathrm{P} \leq 0.05)$ for Varieties $=0.17, \mathrm{LSD}(\mathrm{P} \leq 0.05)$ for Treatments $\mathrm{x}$ Varieties $=0.34$

Figure 3. Effect of Bacterium-RKN double infection on plant yield (kg.plant ${ }^{-1}$ )

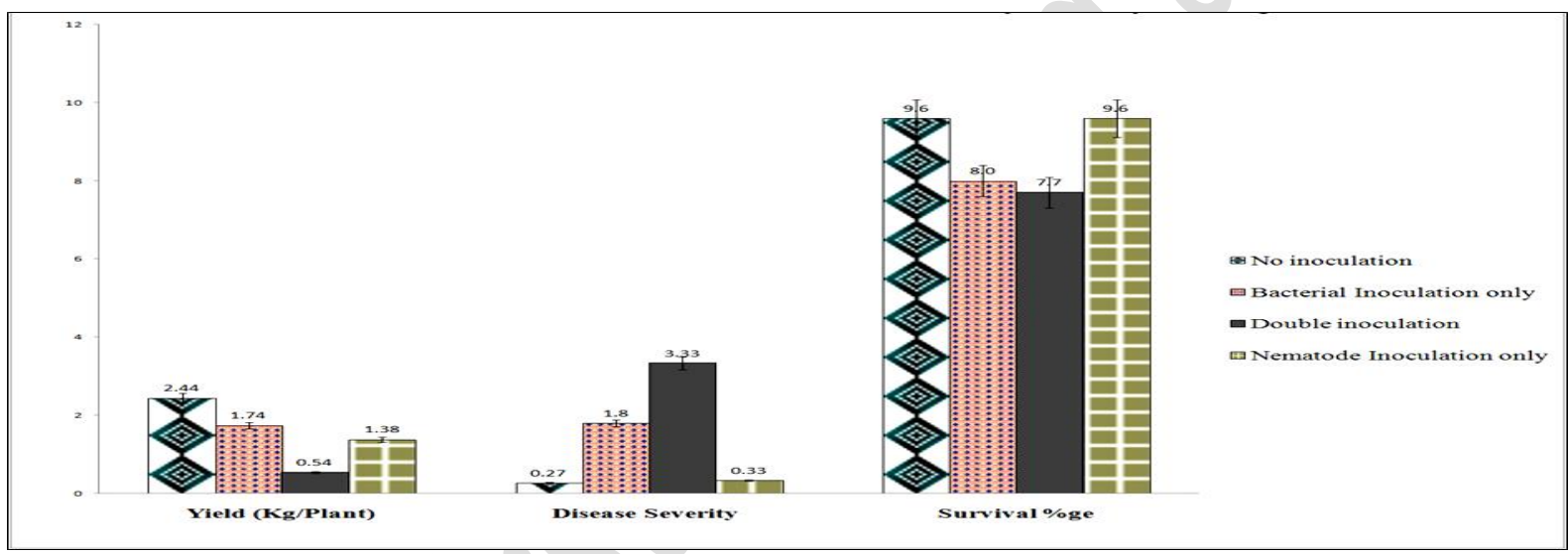

LSD $(\mathrm{P} \leq 0.05)$ for Yield $=0.15$, LSD $(\mathrm{P} \leq 0.05)$ for Disease severity=0.32, LSD $(\mathrm{P} \leq 0.05)$ for Survival percentage $=3.91$

Figure 4.Effect of Bacterium-RKN double infection on yield, disease severity and survival percentage

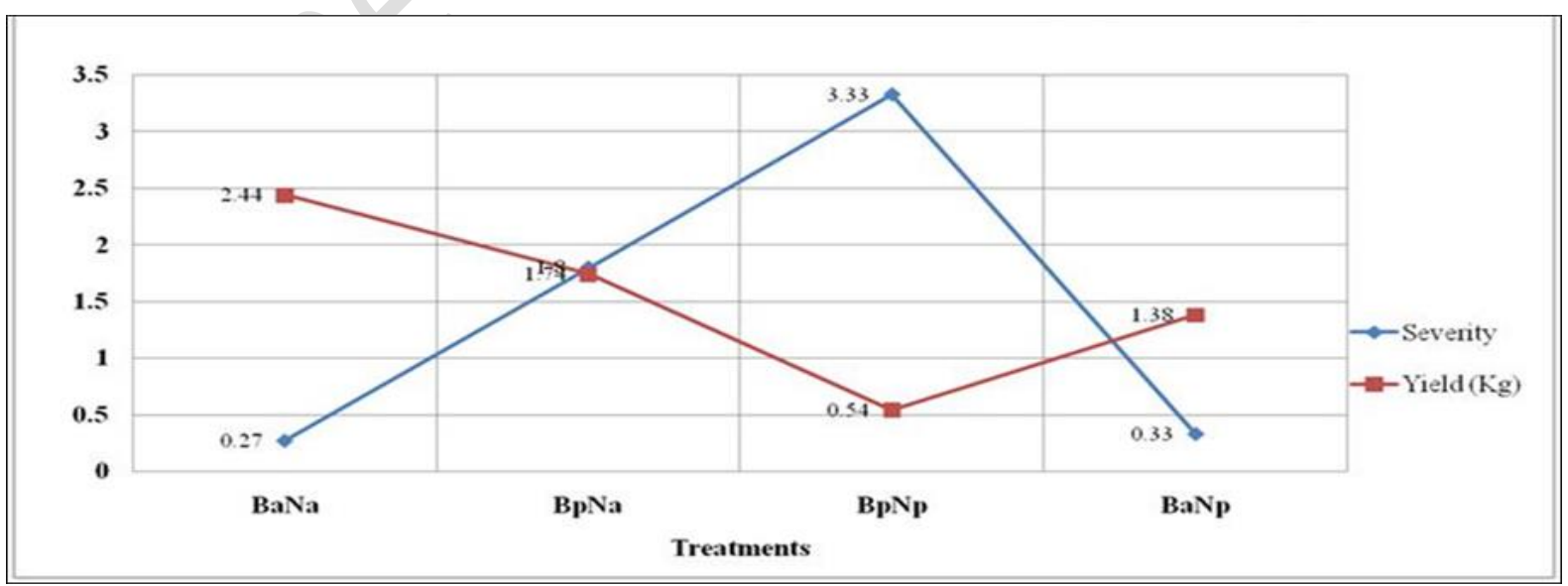

$\mathrm{B}=$ Bacteria, $\mathrm{N}=$ Nematode, $\mathrm{a}=$ absent, $\mathrm{p}=$ present, $\mathrm{LSD}(\mathrm{P} \leq 0.05)$ for Treatments $($ Severity $)=0.32, \mathrm{LSD}(\mathrm{P} \leq 0.05)$ for Varieties (Severity) $=0.36$, LSD $(\mathrm{P} \leq 0.05)$ for Treatments $x$ Varieties (Severity) $=0.73$, LSD $(\mathrm{P} \leq 0.05)$ for Treatments $($ Yield $)=0.15, \operatorname{LSD}(\mathrm{P} \leq 0.05)$ for Varieties (Yield $)=0.17$, LSD $(\mathrm{P} \leq 0.05)$ for Treatments $\mathrm{x}$ Varieties (Yield) $=0.34 \mathrm{~s}$

Figure 5. Effect of Bacterium-RKN double infection on disease severity and yield 


\section{Discussion}

Root-knot and cyst nematodes have been found to predispose plants to heavier infection by other pathogens [10-13]. Rootknot nematodes (RKN), Meloidogyne spp., are of great importance in severe outbreaks of bacterial wilt [14]. In our studies we found that when RKN was inoculated together with $R$. solanacearum, severity of bacterial wilt enhanced significantly. Our results are in agreement with previous findings $[14,15]$ which reported that double infection of RKN and $R$. solanacearum resulted in significant increase in severity of bacterial wilt even on resistant tomato cultivars. However, in survival percentage both the un-inoculated and inoculated with only bacteria showed statistically similar results indicated that RKN needs more time for its infection and establishment within the roots and root zone of the plants. RKN predispose tomato plants to bacterial wilt by severely injuring and making them week. Wounding reduces the time needed for bacterial invasion in the root system [16]. Moreover, when a plant is severely infected by RKN, the normal root system is reduced to a limited number of severely galled roots, with a completely disorganized vascular system. These roots are seriously hampered in their main functions of uptake and transport of water and nutrients [20]. Some previous findings [21] suggest that the role of RKN in augmenting bacterial wilt severity might be more than just producing wounds for the entry of the bacterial pathogen into plant tissues and causing the root system to disfunction. These researchers were of the view that RKN-induced stress was more important as a wilt-triggered factor than the wounding. Other researchers [22, 23] found that RKN infection caused considerable biochemical changes in the diseased plant resulting in weakening of its chemical resistance mechanisms that led to enhancement of wilt. Further research is needed, especially on finding new, environment friendly components of the IDM against bacterial wilt of tomato.

\section{Conclusion and recommendation}

From the present research it can be concluded that that Root-knot nematode having a synergistic effect on bacterial wilt diseases, if inoculated together with $R$. solanacearum and it is recommended rootknot nematodes should be managed properly to reduce the impact of bacterial wilt disease in tomato.

\section{Authors' contributions}

Conceived and designed the experiments: M Junaid \& M Ahmad, Performed the experiments: M Junaid, Analyzed the data: M Junaid, Contributed materials/analysis tools: Saifullah, Wrote the paper: $M$ Junaid.

\section{Acknowledgments}

The authors extends their thanks to Higher education of Pakistan (HEC) for funding the current research.

\section{References}

1. Smith, AF (1994).The tomato in America: early history, culture, and cookery. Columbia, SC, USA: University of South Carolina Press, pp 38.

2. MINFAL (2013) Agricultural statistics of Pakistan. Ministry of Food, Agriculture. Livestock (Economic Wing), Islamabad.

3. FAOSTAT (2015) FAO (Food and Agricultural Organization of the United Nations). Available online at: http://faostat.fao.org.

4. Nowicki M, Kozik EU \& Foolad MR (2013) Late blight of tomato. Translational genomics for crop breeding, volume I: biotic stress. 1st edn. Varshney RK, Tuberosa R (eds) Wiley, Hoboken.

5. Bibi A \& Musharaf A (2016) Effect of irrigation intervals and soil types on yield and yield components of tomato plants artificially inoculated with Clavibacter Michiganensis subsp. Michiganensis. Pure Appl Biol 5(4): 793-803.

6. Huang J, Wei Z, Tan S, Mei X, Yin S, Shen Q \& Xu Y (2013). The rhizosphere soil of diseased tomato plants as a source 
for novel microorganisms to control bacterial wilt. Appl Soil Ecol 72: 79-84.

7. Singh S, Gautam RK, Singh DR, Sharma TVRS, Sakthivel K \& Roy SD (2015) Genetic approaches for mitigating losses caused by bacterial wilt of tomato in tropical islands. Eur J Plant Pathol 143: 205-221.

8. Ono K, Hara H \& Akazawa J (1984) Ecological studies on the bacterial wilt, caused by Pseudomonas solanacearum. $\mathrm{V}$. The movement of the pathogen in tobacco plants. Bulletin of the Okayama Tob Exper Station 43: 41-46.

9. Murakoshi S \& Takahashi M (1984) Trials of some control of tomato wilt caused by Pseudomonas solanacearum. Bulletin of the Kanagawa Horticultural Experiment Station. 31: 50-56.

10. Carter WW (1981). The effect of Meloidogyne incognita and tissue wounding severity of seedling disease of cotton caused by Rhizoctonia solani. $J$ Nematol 31: 374-376.

11. Sumner DR \& Minton NA (1987) Interaction of Fusarium wilt and nematodes in Cobb soybean. Plant Dis 71: 20-23.

12. Roy KW, Lawrence GW, Hodges HH, McLean KS \& Killebrew JF (1989) Sudden death syndrome of soybean: Fusarium solani as incitant and relation of Heterodera glycines to disease severity. Phytopathol. 79: 191-197.

13. McLean KS \& Lawrence GW (1993) Interrelationship of Heterodera glycines and Fusarium solani in sudden death syndrome. J Nematol 25: 434-439.

14. Deberdta P, Queneherveb P, Darrassea A \& Priora P (1999) Increased susceptibility to bacterial wilt in tomatoes by nematode galling and the role of the $\mathrm{Mi}$ gene in resistance to nematodes and bacterial wilt. Plant Pathol 48: 408-414.

15. Bekhiet MA, Kella AM, Khalil AE \& Tohamy AA (2010) Interaction between root-knot nematode, Meloidogyne incognita and the bacterium, Ralstonia solanacearum on potato. J Plant Prot Pathol 1(7): 505-518.

16. Cadet P, Prior P \& Steva H (1989) Influence de Meloidogyne arenaria sur la sensibilite' de deux cultivars de tomate a'Pseudomonas solanacearum EF Smith dans les Anti. Franc Lagron Tropi 44: 263-268.

17. Atamian HS, Roberts PA \& Kaloshian I (2012). High and low throughput screens with root-knot nematodes Meloidogyne spp., J Vis Exp 61: 3629.

18. French EB, Gutarra L, Aley $\mathrm{P} \&$ Elphinstone J (1995). Culture media for Ralstonia solanacearum isolation, identification, and maintenance. Fitopatol 30(3): 126-130.

19. Swanson JK, Yao J, Kersten JKT \& Allen C (2005) Behavior of Ralstonia solanacearum race 3 biovar 2 during latent and active infection of geranium. Phytopathol 95: 136-143.

20. Netscher C \& Sikora RA (1990) Nematode parasites of vegetables. In: Plant Parasitic Nematodes in Subtropical and Tropical Agriculture (Eds. Luc M, Sikora RA, Bridge J). pp 237-283. Wallingford UK: CAB International.

21. Sitaramaiah K \& Sinha SK (1984) Interaction between Meloidogyne javanica and Pseudomonas solanacearum on brinjal. Ind J Nematol 14: 1-5.

22. Trudgill DL (1991) Resistance to and tolerance of plant parasitic nematodes in plants. Annu Rev Phytopathol 29: 167192.

23. Khan MW (1993) Mechanisms of interactions between nematodes and other plant pathogens. In: Nematode Interactions. (Ed. Khan MW). Chapman and Hall. Madras, India, pp 55-78. 